\begin{tabular}{|l|l|l||}
\hline \multicolumn{2}{|c|}{ PublisherInfo } \\
\hline \hline PublisherName & $:$ & BioMed Central \\
\hline \hline PublisherLocation & $:$ & London \\
\hline \hline PublisherImprintName & $:$ & BioMed Central \\
\hline \hline
\end{tabular}

\title{
Where is the proteome?
}

\begin{tabular}{|l|l|l||}
\hline \multicolumn{2}{|c||}{ ArticleInfo } \\
\hline \hline ArticleID & $:$ & 4424 \\
\hline \hline ArticleDOI & $:$ & 10.1186 /gb-spotlight-20020318-01 \\
\hline \hline ArticleCitationID & $:$ & spotlight-20020318-01 \\
\hline \hline ArticleSequenceNumber & $:$ & 90 \\
\hline \hline ArticleCategory & $:$ & Research news \\
\hline ArticleFirstPage & $:$ & 1 \\
\hline \hline ArticleLastPage & $:$ & 2 \\
\hline \hline & & RegistrationDate : 2002-3-18 \\
\hline ArticleHistory & $:$ & OnlineDate \\
\hline \hline ArticleCopyright & $:$ & BioMed Central Ltd2002-18 \\
\hline \hline ArticleGrants & $:$ & \\
\hline \hline ArticleContext & $:$ & 130593311 \\
\hline \hline
\end{tabular}




\section{Anna Sharman}

Email: anna@genomebiology.com

Where a protein is found in a cell can reveal a lot about its function. In the March 15 Genes and Development, Kumar and colleagues report the subcellular localization of 2,744 proteins in the budding yeast, Saccharomyces cerevisiae. They tagged the proteins with an easy-to-detect epitope, mostly using direct cloning but for some using random transposon mutagenesis, and examined the subcellular localization of the tagged proteins using immunofluorescence. Together with previously published data (some reviewed previously by Pepperkok et al. in Genome Biology), these results mean that the subcellular localization of over half of the yeast proteome is known. The functions of nearly 1,000 of the proteins localized in the study by Kumar et al. were previously unknown, so it may now be possible to explore their potential roles on the basis of where they are found in the cell. Extrapolating their results to the whole proteome, the authors estimate that just under half of all yeast proteins are cytoplasmic, a quarter are nuclear (of which around one third are associated with the chromosomes), and the rest are mitochondrial, secreted or in various other compartments. The authors provide a database of these data.

\section{References}

1. Genes and Development, [http://www.genesdev.org/]

2. Being in the right location at the right time, [http://genomebiology.com/2001/2/9/reviews/1024/]

3. Yale genome analysis center, [http://ygac.med.yale.edu] 